\title{
Undernutrition among Tuberculosis Patients on Directly Observed Short-Course Therapy: An Epidemiological Study from Northern Ethiopia
}

\author{
Tsige Brhane' \\ Hailu Merga $\left(\mathbb{D}^{2}\right.$ \\ Lalisa Ayele ${ }^{3}$ \\ Desta $\mathrm{H}$ Gemeda ${ }^{2}$
}

'Public Health Department, International Organization for Migration, Addis Ababa, Ethiopia; ${ }^{2}$ Epidemiology Department, Institute of Health, Jimma University, Jimma, Ethiopia; ${ }^{3}$ School of Midwifery, Institute of Health, Jimma University, Jimma, Ethiopia
Correspondence: Hailu Merga Epidemiology Department, Institute of Health, Jimma University, Jimma, Ethiopia Tel +251 91-064-8439

Email hailu.merga2014@gmail.com
Background: Tuberculosis (TB) makes undernutrition worse and undernutrition weakens immunity, thereby increasing the likelihood that latent TB will develop into active disease. This may result due to illness that impairs nutrient intake and metabolism or results from inadequate intake of macronutrients, micronutrients, or both. This study aimed to assess undernutrition and associated factors among adult patients on directly observed therapy short course (DOTS) for TB in public-health facilities of the central and northwestern zones of Tigray, Ethiopia.

Methods: A facility-based cross-sectional study was conducted among 406 adult TB patients from June 15 to July 15, 2019. Data were collected using an interviewer-administ ered pretested structured questionnaire, entered into EpiData version 3.1, and exported to SPSS 20 for analysis. Abinary logistic regression model was fitted to assess factors associated with undernutrition. Statistical significance was declared at $P<0.05$.

Results: The prevalence of undernutrition was $45.6 \%$, (95\% CI $40.76 \%-50.44 \%$ ), with $24.4 \%$ mild, $11.3 \%$ moderate, and $9.9 \%$ severe undernutrition. Age $>40$ years AOR 2.13, 95\% CI 1.02-4.55), pulmonary TB (AOR 3.36, 95\% CI 1.877-6.012), pulmonary-negative TB -(AOR 1.82, 95\% CI 1.055-3.126), eating problems (AOR 2.71, 95\% CI 1.443, 5.105), and income $<$ ETB800 AOR 3.31, 95\% CI 1.655-6.607) and ETB800-1,500 (AOR 2.845, 95\% CI 1.368-5.917) were factors independently associated with undernutrition.

Conclusion: The prevalence of undernutrition was found to be high among adult TB patients. Age $>40$ years, pulmonary-positive and pulmonary-negative TB, eating problems, and income $<$ ETB800, and ETB800-1,500 were predictors of undernutrition. Therefore, mainstream nutrition assessment in health programs and early detection and treatment are needed for TB cases to improve their nutritional status.

Keywords: undernutrition, directly observed therapy, epidemiology, Ethiopia

\section{Plain-Language Summary}

Tuberculosis (TB) makes undernutrition worse and undernutrition weakens immunity, which increases the development of latent TBTB into active disease. A facility-based cross-sectional study was conducted among 406 adult TBTB patients from June 15 to July 15, 2019 to assess the prevalence of undernutrition and associated factors among those on directly observed therapy - short-course for TB in public-health facilities of the central and northwestern zones of Tigray, Ethiopia. Findings showed that the prevalence of undernutrition was high $(45.6 \%)$. Age of patients with pulmonary TB, pulmonary-negative TB, eating 
problems, and incomes $<$ ETB800 were identified as determinants of undermatron. Therefore, mainstream-nutrition assessment in health programs and early detection, treatment of TB cases need to be done to improve their nutritional status.

\section{Background}

Undernutrition is a state in which health and growth are limited when the nutritional status of the person is suboptimal. It may be related to an illness that weakens nutrient intake and metabolism or results from insufficient intake of macronutrients, micronutrients, or both. ${ }^{1}$ Tuberculosis (TB) is the most common global cause of death, and $>95 \%$ of TB deaths occur in low- and middleincome countries. Poverty and resource inequity are often common denominators in TB cases, and treatment outcomes can be enhanced by considering and studying patients' nutritional status. TB causes significant morbidity and mortality in resource-limited settings and malnutrition is also common in resource-limited settings, particularly in sub-Saharan Africa. Globally in 2019, an estimated 10 million people fell ill with $\mathrm{TB}$ and there were an estimated 1.2 million TB deaths among HIV-negative people. The TB-incidence rate is falling globally, though the decline was not quick enough to reach the 2020 milestone reduction of $20 \%$ from 2015 to $2020 .^{2-5}$ A study from Mozambique showed that social determinants of health have a crucial role in improving TB patients' outcomes and global TB burden. ${ }^{6}$

TB has been recognized as a major public health problem in Ethiopia for more than half a century. Ethiopia is ranked tenth among the 22 countries with a high TB burden. A finding from the Tigray region showed that the prevalence of multidrug-resistant (MDR) TB was $18.5 \%$ and that age was predictor. ${ }^{5-8}$

$\mathrm{TB}$ is not only a significant and preventable cause of morbidity and mortality but also a major cause of poverty aggravation, as people with TB frequently face the double burden of lower income and higher expenses. ${ }^{9,10}$ Very high health expenditure by TB patients is a common consequence of TB diagnosis, treatment, and care, and is associated with adverse TB outcomes. This often leads to worsening food insecurity for patients and their families during the disease. ${ }^{11,12}$

Patients with poor nutrition are at increased risk of TB. Undernutrition and TB are directly related problems in most ounderdeveloped countries, including Ethiopia. Poor nutritional status, especially for TB patients, increases the risk of poor clinical outcomes, including death, and enhances transmission of TB in the community. Though there have been a few studies on undernutrition among TB patients on directly observed therapy - short course (DOTS), there have been no study conducted in the area. Therefore, this study was aimed to assess undernutrition and associated factors among adult TB patients under directly observed therapy in central and northwestern Tigray zone.

\section{Methods}

\section{Study Design and Setting}

A facility-based cross-sectional study was conducted in the central and northwestern zones of Tigray state from June 15 to July 15, 2019. This area is in northern Ethiopia and has a population of 67,155 of which $16 \%$ are aged $<$ five years. There are 96 public-health centers and five public hospitals in these zones.

\section{Population and Sampling}

All TB patients who were on DOT and aged greater than or equal to 18 years were included in the study during the study period. Patients with MDR TB or unable to communicate and pregnant women were excluded from the study.

Sample size was calculated using EpiInfo 7.1 using parameters of $49 \%$ undernutrition among TB patients who have received dietary counseling, ${ }^{12} 1.8$ AOR, 95\% confidence level, and $80 \%$ power. Finally, after adding a $10 \%$ nonresponse rate, 440 adult TB patients were required. Of 48 health centers providing TB-treatment services in the central and northwestern zones, 20 were selected using computer-generated simple random sampling based on recent TB patient follow-up. Then, the total sample size was proportionally allocated to the number of adult TB patients at each selected health center and participants interviewed consecutively.

\section{Data-Collection Tool and Procedure}

Data were collected using an interviewer-administered pretested structured questionnaire in health facilities. The questionnaire was prepared in English after a review of related literature, translated to the local language (Tigrigna), then back-translated to English by professional translators who had good skills in Tigrigna and English translation to ensure consistency. Pretest was conducted on $5 \%$ of the sample size in health facilities outside the study area and not included in the final analysis. Necessary 
corrections were made based on the results. Weight and height scales for were checked and calibrated to make measurements more reliable and minimize errors. To measure weight, patients needed to remove their shoes, be wearing minimal clothing, and stand erect on the center of the balance. Weight was recorded to the nearest $0.1 \mathrm{~kg}$. Height was measured after ensuring patient was barefoot, wearing no headgear, with knees fully straight and both hands held down at their sides. Height was record the to the nearest $0.5 \mathrm{~cm}$. To improve the quality of the data, data collectors were trained and closely supervised, and each completed questionnaire was checked by the supervisor to ascertain whether all questions had been correctly completed.

\section{Data Analysis}

Data were checked for completeness, coded, and entered into EpiData 3.1, then exported to SPSS 20 for further analysis. Both descriptive and inferential analyses were conducted. Binary logistic regression models were fitted to assess associations between undernutrition and independent variables. All independent variables associated with undernutrition on bivariate analyses with $P<0.25$ were included in the final multivariate logistic analysis. Multicollinearity was checked using the varianceinflation factor, which was between 1 and 10, indicating absence of any significant collinearity between explanatory variables. Model adequacy was checked using the Hosmer-Lemeshow goodness-of-fit test, with a result of $P=0.115$. AORs and $95 \%$ CIs were computed. $P<0.05$ was considered statistically significant.

\section{Results}

\section{Sociodemographic Characteristics of Respondents}

A total of 406 adult TB patients were involved in the study, a response rate of $92.5 \%$. The median age of the study participants was 39 (IQR 27-51) years, with a minimum age of 18 years and maximum 87 years. More than half $(58.4 \%)$ the respondents were male, and about two-thirds (66.3\%) were married. A majority $(43.1 \%)$ of the respondents had no formal education, and more than half $(53.2 \%)$ were living in rural areas (Table 1).

Of the 406 respondents, $210(51.7 \%)$ had not recived any dietary counseling by trained clinicians and 76 $(18.7 \%)$ had received nutritional support from any organization. The mean individual dietary diversity score of patients was $7.559 \pm 2.183$. A large majority (89.7\%) of respondents consumed three or more meals per day, more than a third $(37.4 \%)$ had pulmonary-negative $\mathrm{TB}$, and more than half $(60.1 \%)$ had been on anti-TB treatment $\leq 4$ weeks (Table 2).

\section{Nutritional Status of Adult TB Patients on DOTS}

This study revealed that $185(45.6 \%)$ respondents were undernourished. Of these, $9.9 \%, 11.3 \%$, and $24.4 \%$ were severely, moderately, and mildly undernourished, respectively. Furthermore, 203 (50\%) and 18 (4.4\%) were normal weight and overweight, respectively, and none of them were obese.

\section{Factors Associated with Undernutrition among Adult TB Patients on DOTS}

On bivariate analysis, age $>40$ years (COR:2.1, 95\% CI 1.229-3.549), no formal education (COR:2.2, 95\% CI 1.179-4.202), rural residence (COR: $1.5,95 \%$ CI 1.030-2.266), income <ETB800 (COR: 3.5, 95\% CI 2.039-6.024), income 800-1,500ETB (COR: 2.6, 95\% CI 1.391-4.815), pulmonary-positive TB (COR: 3.6, 95\% CI 2.123-6.007), pulmonary-negative TB (COR: 2.1, 95\% CI 1.250-3.346), ambulatory/bedridden (COR: 1.9, 95\% CI 1.192-2.649), no counseling (COR: 3.8, 95\% CI 2.515-5.762), and eating problems (COR: 2.9, 95\% CI 1.663-5.241) were factors significantly sssociated with undernutrition $(P<0.05)$.

After controlling for other variables, age, income, type of $\mathrm{TB}$, and eating problems remained significantly associated with undernutrition $(P<0.05)$. The odds of undernutrition among participants aged $>40$ years were double those of participants aged $<24$ years (AOR 2.1, 95\% CI 1.015-4.545). The odds of undernutrition among individuals earning $<$ ETB800 and ETB8001,500 were 3.3 (95\% CI 1.655-6.607) and 2.8 (1.368-5.917) times those of participants earning $>$ ETB 1,500 , respectively. The odds of undernutrition among pulmonary-positive and pulmonary-negative TB patients were 3.4 (95\% CI 1.877-6.012) and 1.8 (95\% CI 1.055-3.126) times those of extrapulmonary TB cases, respectively. The odds of undernutrition among patients who had eating problems were 2.7 (95\% CI 1.443-5.105) times those of patients who had no eating problems (Table 3). 
Table I Sociodemographic characteristics of adult TB patient's on DOTS in northwestern and central zones of Tigray, Ethiopia, $2019(n=406)$

\begin{tabular}{|c|c|c|c|}
\hline & Category & $\begin{array}{l}\text { Frequency } \\
\text { (n) }\end{array}$ & $\begin{array}{l}\text { Percentage } \\
\text { (\%) }\end{array}$ \\
\hline \multirow[t]{4}{*}{ Age, years } & $<24$ & 84 & 20.7 \\
\hline & $24-30$ & 40 & 9.9 \\
\hline & $31-40$ & 92 & 22.7 \\
\hline & $>40$ & 190 & 46.8 \\
\hline \multirow[t]{2}{*}{ Sex } & Male & 237 & 58.4 \\
\hline & Female & 169 & 41.6 \\
\hline \multirow[t]{3}{*}{ Religion } & Orthodox & 332 & 81.8 \\
\hline & Muslim & 69 & 17 \\
\hline & Other* & 5 & 1.2 \\
\hline \multirow[t]{2}{*}{ Marital status } & Married & 269 & 66.3 \\
\hline & Unmarried & 137 & 33.7 \\
\hline \multirow[t]{2}{*}{ Occupation } & Employed & 349 & 86 \\
\hline & Unemployed & 57 & 14 \\
\hline \multirow[t]{5}{*}{ Education } & None & 175 & 43.1 \\
\hline & Primary school & 71 & 17.5 \\
\hline & Secondary & 107 & 26.4 \\
\hline & school & & \\
\hline & $\begin{array}{l}\text { Diploma or } \\
\text { higher }\end{array}$ & 53 & 13.1 \\
\hline \multirow[t]{2}{*}{ Residence } & Urban & 190 & 46.8 \\
\hline & Rural & 216 & 53.2 \\
\hline \multirow[t]{2}{*}{ Family size } & $\leq 4$ & 225 & 55.4 \\
\hline & $>4$ & 181 & 44.6 \\
\hline \multirow{4}{*}{$\begin{array}{l}\text { Monthly income, } \\
\text { ETB }\end{array}$} & $\leq 800$ & 219 & 53.9 \\
\hline & & & \\
\hline & $800-1,500$ & 95 & 23.4 \\
\hline & $\geq 1,500$ & 92 & 22.7 \\
\hline
\end{tabular}

Note: *Catholic, Protestant.

\section{Discussion}

The prevalence of undernutrition in this study was found to be $45.6 \%$, which was much lower than studies done in Malawi (57\%), ${ }^{13}$ Ghana (51\%), ${ }^{14}$ Tripura Hospital, India $(66 \%)^{12}$ and West Bengal, India (66\%), ${ }^{15}$ and still lower than other studies from Ethiopia: in Adama $(53 \%)^{16}$ and Gondar $(71.4 \%) .{ }^{17}$ Our result is similar to findings from Uganda $(46 \%),{ }^{18}$ but higher than reports from Kenya (43\%), ${ }^{19}$ Addis Ababa, Ethiopia (39.7\%), ${ }^{20}$ and Hosanna, southern Ethiopia (38.9\%). ${ }^{21}$ The difference may be explained by differences in socioeconomic status, study area, lifestyles, feeding patterns, economic status of the countries, and sample sizes. Moreover, in some of these
Table 2 Nutrition-intervention history, household hunger scale, type of TB, and illness in adult TB patients in northwestern and central zones of Tigray, $2019(n=406)$

\begin{tabular}{|c|c|c|c|}
\hline & Category & $\begin{array}{l}\text { Frequency } \\
\text { (n) }\end{array}$ & $\begin{array}{l}\text { Percentage } \\
\text { (\%) }\end{array}$ \\
\hline $\begin{array}{l}\text { Nutritional care } \\
\text { and support }\end{array}$ & $\begin{array}{l}\text { Yes } \\
\text { No }\end{array}$ & $\begin{array}{l}76 \\
330\end{array}$ & $\begin{array}{l}18.7 \\
81.3\end{array}$ \\
\hline $\begin{array}{l}\text { Received dietary } \\
\text { counseling }\end{array}$ & $\begin{array}{l}\text { Yes } \\
\text { No }\end{array}$ & $\begin{array}{l}196 \\
210\end{array}$ & $\begin{array}{l}48.3 \\
51.7\end{array}$ \\
\hline $\begin{array}{l}\text { Eating frequency } \\
\text { per day }\end{array}$ & $\begin{array}{l}\leq 2 \\
\geq 3\end{array}$ & $\begin{array}{l}42 \\
364\end{array}$ & $\begin{array}{l}10.3 \\
89.7\end{array}$ \\
\hline $\begin{array}{l}\text { Household } \\
\text { Hunger Scale }\end{array}$ & $\begin{array}{l}\text { Little or no } \\
\text { hunger } \\
\text { Moderate/ } \\
\text { severe hunger }\end{array}$ & $\begin{array}{l}401 \\
5\end{array}$ & $\begin{array}{l}98.8 \\
1.2\end{array}$ \\
\hline $\begin{array}{l}\text { Individual dietary } \\
\text { diversity score }\end{array}$ & $\begin{array}{l}\text { Nondiversified } \\
\text { Diversified }\end{array}$ & $\begin{array}{l}194 \\
212\end{array}$ & $\begin{array}{l}47.8 \\
52.2\end{array}$ \\
\hline TB type & $\begin{array}{l}\text { Pulmonary- } \\
\text { positive } \\
\text { Pulmonary- } \\
\text { negative } \\
\text { Extrapulmonary }\end{array}$ & $\begin{array}{l}124 \\
152 \\
130\end{array}$ & $\begin{array}{l}30.5 \\
37.4 \\
32\end{array}$ \\
\hline $\begin{array}{l}\text { Duration on anti- } \\
\text { TB medication }\end{array}$ & $\begin{array}{l}\leq 4 \text { weeks } \\
5-8 \text { weeks }\end{array}$ & $\begin{array}{l}244 \\
162\end{array}$ & $\begin{array}{l}60.1 \\
39.9\end{array}$ \\
\hline Functional status & $\begin{array}{l}\text { Working } \\
\text { Ambulatory } \\
\text { Bedridden }\end{array}$ & $\begin{array}{l}178 \\
225 \\
3\end{array}$ & $\begin{array}{l}43.8 \\
55.4 \\
7\end{array}$ \\
\hline Eating problem & $\begin{array}{l}\text { Yes } \\
\text { No }\end{array}$ & $\begin{array}{l}62 \\
344\end{array}$ & $\begin{array}{l}15.3 \\
84.7\end{array}$ \\
\hline $\begin{array}{l}\text { Reason for eating } \\
\text { problem }\end{array}$ & $\begin{array}{l}\text { Mouth ulcer } \\
\text { Nausea or } \\
\text { vomiting } \\
\text { Poor appetite } \\
\text { Pain or } \\
\text { difficulty } \\
\text { swallowing }\end{array}$ & $\begin{array}{l}5 \\
27 \\
27 \\
3\end{array}$ & $\begin{array}{l}8.1 \\
43.5 \\
\\
43.5 \\
4.8\end{array}$ \\
\hline $\begin{array}{l}\text { Chronic illness } \\
(n=40)\end{array}$ & $\begin{array}{l}\text { HIV/AIDS } \\
\text { Diabetes } \\
\text { mellitus } \\
\text { Hypertension } \\
\text { Other* }\end{array}$ & $\begin{array}{l}25 \\
6 \\
7 \\
2\end{array}$ & $\begin{array}{l}62.5 \\
15 \\
17.5 \\
5\end{array}$ \\
\hline
\end{tabular}

Notes: *Epilepsy.

studies, participants' BMI was taken at the time of diagnosis before starting anti-TB medication, others when patients had not recovered from their illness, others within 2 months in a state of critical undernourishment, which could overestimate the expected level of undernutrition. 
Table 3 Factors associated with undernutrition among adult TB patients on DOTS in public-health faculties, northwestern and central zones of Tigray, Ethiopia, $2019(n=406)$

\begin{tabular}{|c|c|c|c|c|c|}
\hline & \multirow[t]{2}{*}{ Category } & \multicolumn{2}{|c|}{ Undernutrition } & \multirow[t]{2}{*}{ COR $(95 \% \mathrm{Cl}$} & \multirow[t]{2}{*}{ AOR $(95 \% \mathrm{Cl})$} \\
\hline & & Yes, n (\%) & No, n (\%) & & \\
\hline Age, years & $\begin{array}{l}<24 \\
24-30 \\
31-40 \\
>40\end{array}$ & $\begin{array}{l}30(16.2) \\
21(11.4) \\
32(17.3) \\
102(55.1)\end{array}$ & $\begin{array}{l}54(24.4) \\
19(8.6) \\
60(27.1) \\
88(39.8)\end{array}$ & $\begin{array}{l}\text { I } \\
\text { I.989 (0.92-4.273) } \\
0.960(0.517-I .783) \\
2.086(I .229-3.543)\end{array}$ & $\begin{array}{l}\text { I } \\
2.009(0.846-4.77 I) \\
0.931(0.436-1.987) \\
2.148(1.015,4.545)^{*}\end{array}$ \\
\hline ncome, ETB & $\begin{array}{l}<800 \\
800-1,500 \\
>1,500\end{array}$ & $\begin{array}{l}118(63.8) \\
44(23.8) \\
23(12.4)\end{array}$ & $\begin{array}{l}I 0 I(45.7) \\
5 I(23.1) \\
69(3 I .2)\end{array}$ & $\begin{array}{l}3.505(2.039-6.024) \\
2.588(1.39 \mid-4.815) \\
I\end{array}$ & $\begin{array}{l}\left.3.307(1.655-6.607)^{*}\right) \\
2.845(1.368-5.917)^{*} \\
\text { । }\end{array}$ \\
\hline TB type & $\begin{array}{l}\text { Pulmonary-positive } \\
\text { Pulmonary-negative TB } \\
\text { Extrapulmonary }\end{array}$ & $\begin{array}{l}75(40.5) \\
71(38.4) \\
39(21.1)\end{array}$ & $\begin{array}{l}49(22.2) \\
81(36.7) \\
91(41.2)\end{array}$ & $\begin{array}{l}3.57 \mid(2.123-6.007) \\
2.045(1.25-3.346) \\
I\end{array}$ & $\begin{array}{l}3.359(1.877-6.012)^{*} \\
1.816(1.055-3.126)^{*} \\
I\end{array}$ \\
\hline Eating problem & $\begin{array}{l}\text { Yes } \\
\text { No }\end{array}$ & $\begin{array}{l}42(22.7) \\
143(77.3)\end{array}$ & $\begin{array}{l}20(9.0) \\
201(91.0)\end{array}$ & $\begin{array}{l}2.952(I .66-5.24 I) \\
I\end{array}$ & $\begin{array}{l}2.714(1.443-5.105)^{*} \\
\text { I }\end{array}$ \\
\hline
\end{tabular}

Notes: $* P<0.05$

This study revealed that age was associated with undernutrition, with the most affected group aged $>40$ years. The odds of undernutrition among participants aged $>40$ years were about two times higher than those patients aged $<24$ years. This result is in line with a finding from Italy, which showed that older people with TB were a vulnerable group with high mortality, ${ }^{22}$ but not consistent with a study from India, which revealed the opposite finding. ${ }^{23}$ The difference might be due to the different socioeconomic status of the populations. Moreover, slower metabolism, lower immunity, and less testing ability in old age can lead to undernutrition.

Average monthly income showed a significant association with undernutrition. The likelihood of participants being undernourished increased when average monthly income was $<$ ETB1,500 per month, in line with a study from Ghana. ${ }^{14}$ The reason for undernutrition among those households with lower monthly income may be their lower purchasing power for food and inability to afford a healthy living environment. Moreover, participants may have underreported their income due to misunderstanding the study objective.

Eating problems, mainly poor appetite, had a significant association with undernutrition. The odds of undernutrition among adult TB patients who had a problem with eating were about 2.7 times higher compared to those of patients who did not have an eating problem. This finding is in line with astudy conducted in
Shashamane, southern Ethiopia; ${ }^{24}$ however, it is inconsistent with a study done in public-health institutions of Addis Ababa, Ethiopia, ${ }^{20}$ which might be due to differences in infrastructure, awareness of healthyg behavior, and duration on anti-TB medication, because this study involved only patients who had been taking medication for up to 2 months, which was the expected time for them to start recovering from the disease, in whom there were fewer episodes of loss of appetite.

The odds of undernutrition among pulmonary-positive and pulmonary-negative adult TB patients were 3.4 and 1.8 times those of extrapulmonary TB cases, respectively. This is consistent with a study conducted in the Wolayita, southern Ethiopia, ${ }^{25}$ and low BMI was found among pulmonary-positive patients in Kenya. ${ }^{19}$ However, our result is not consistent with studies done in Shashemane ${ }^{24}$ and Addis Ababa, Ethiopia. ${ }^{20}$

Although this study has its strengths, such as the use of a standardized data-collection tool, it has the limitations of information bias and recall bias during interviews. Appropriate training was provided to data collectors to minimize these biases.

\section{Conclusion}

The prevalence of undernutrition was found to be high among adult TB patients. Age $>40$ years, pulmonarypositive and pulmonary-negative $\mathrm{TB}$, eating problems, 
and earning $<$ ETB1,500 were predictors of undernutrition. Therefore, mainstream nutrition assessment in publichealth programs, early detection and treatment of $\mathrm{TB}$ cases is recommended to improve nutritional status.

\section{Abbreviations}

DOTS, directly observed therapy, short course; EPTB, extrapulmonary TB; MDR TB, multidrug-resistant TB; WHO, World Health Organization.

\section{Data Sharing Statement}

All data generated or analyzed during this study are included in this article.

\section{Ethics Approval and Informed Consent}

Ethics clearance was obtained from the ethics review board of the Institute of Health, Jimma University. The verbal informed consent was approved by this committee, and this study was conducted in accordance with the Declaration of Helsinki. A formal letter of permission was obtained from Tigray Regional Health Bureau and presented to the respective health facilities. Verbal informed consent was requested from participants after informing them of the purpose, benefit, and risk of the study. Confidentiality of information was assured accordingly, with names not being registered in the questionnaire. $\mathrm{Du}$ to the voluntary nature of participation in the study, there was the right to withdraw from the study at any time.

\section{Authors Details}

Tsige Brhane: MPH, Public Health Department, International Organization for Migration, Addis Ababa, Ethiopia.

Hailu Merga: Assistant Professor of Epidemiology, Epidemiology Department, Institute of Health, Jimma University, Jimma, Ethiopia.

Lalisa Ayelee: MSc in Maternity Health Nursing, School of Midwifery, Institute of Health, Jimma University, Jimma, Ethiopia.

Desta H Gemeda: Associate Professor of Epidemiology, Epidemiology Departement, Institute of Health, Jimma University, Jimma, Ethiopia.

\section{Acknowledgments}

We would like to thank Jimma University Institute of Health for its support. We are also grateful to the health facilities of the central and northwestern zones of Tigray for provision of the data needed data. Special thanks and appreciation to all those who agreed to participate in this study, mainly the respondents, data collectors, and supervisors.

\section{Author Contributions}

All authors contributed to data analysis, drafting, or revising the article, have agreed on the journal to which the article was submitted, gave final approval to the version to be published, and agree to be accountable for all aspects of the work.

\section{Funding}

The study was funded by the Institute of Health of Jimma University. The organization had no role in the design of the study, data collection, analysis, or interpretation of data, or in writing the manuscript.

\section{Disclosure}

The authors declare that they have no conflicts of interest for this work.

\section{References}

1. World Health Organization. Guideline: Nutritional Care and Support for Patients with Tuberculosis. Geneva: World Health Organization; 2013.

2. World Health Organization. Global Tuberculosis Report 2017. Geneva: World Health Organization; 2017. Available from: https:// apps.who.int/iris/handle/10665/259366. Accessed April 8, 2021.

3. World Health Organization. Global Tuberculosis Report 2020. Geneva: World Health Organization;2020. Licence: CC BY-NC-SA 3.0 IGO.

4. Semba RD, Darnton-Hill I, de Pee S. Addressing tuberculosis in the context of malnutrition and HIV coinfection. Food Nutr Bull. 2010;31(4):S345-64. doi:10.1177/15648265100314S404

5. USAID. Multi-Sectoral Nutrition Strategy 2014-2025. Washington DC; 2014. Available from: https://www.usaid.gov/nutrition-strategy. Accessed April 8, 2021.

6. Pizzol D, Veronese N, Marotta C, et al. Predictors of therapy failure in newly diagnosed pulmonary tuberculosis cases in Beira, Mozambique. BMC Res Notes. 2018;11(1):99. doi:10.1186/s13104018-3209-9

7. WHO. From MDG to SDG. World Health Organization(WHO). Available from:http://apps.who.int/iris/bitstream/10665/200009/1/ 9789241565110_eng.pdf?ua=1. Accessed January 23, 2021.

8. Deribew A, Deribe K, Dejene T, et al. Tuberculosis Burden in Ethiopia from 1990 to 2016: evidence from the Global Burden of Diseases 2016 Study. Ethiop J Health Sci. 2018;28(5):519-528. doi:10.4314/ejhs.v28i5.2

9. Mehari K, Asmelash T, Hailekiros H, et al. Prevalence and Factors Associated with Multidrug-Resistant Tuberculosis (MDR-TB) among Presumptive MDR-TB Patients in Tigray Region, Northern Ethiopia. Can J Infect Dis Med Microbiol. 2019;2019:2923549. doi:10.1155/ 2019/2923549

10. World Health Organization. Global Tuberculosis Report 2015. 20th. World Health Organization; 2015. 
11. Tanimura T, Jaramillo E, Weil D, Raviglione M, Knut L. Financial burden for tuberculosis patients in low and middle income countries: a systematic review. Eur Respir J. 2014;43(6):1763-1775. doi: 10.1183/09031936.00193413

12. Das S, Sen S, Debnath A, Basuthakur S, Saha PK, Biswas C. A study of nutritional assessment of newly diagnosed tuberculosis patients in a tertiary care hospital of Tripura, India. Int J Res Med Sci. 2018;6 (4):1382-1387. doi:10.18203/2320-6012.ijrms20181301

13. Zachariah R, Spielmann M, Harries A, Salaniponi F. Moderate to severe malnutrition in patients with tuberculosis is a risk factor associated with early death. Trans $R$ Soc Trop Med Hyg. 2002;96 (3):291-294. doi:10.1016/S0035-9203(02)90103-3

14. Dodor E. Evaluation of nutritional status of new tuberculosis patients at the effia-nkwanta regional hospital. Ghana Med J. 2008;42(1):22.

15. Nalabothu S, Menon K. Role of serum albumin in monitoring nutritional status in patients with pulmonary tuberculosis. Asian Pac $J$ Health Sci. 2014;4(1):486-491. doi:10.21276/apjhs.2014.1.4.30

16. Guadie F, Assaminew B. Nutritional status and associated factors among adult tb patients on directly observed treatment of short course in health facilities at Adama Town, East Shewa Zone, Ethiopia. Int J Interdisciplinary Stud Business Techn Educ. 2015.

17. Wassie MM. Weight Gain and Associated Factors among Adult Tuberculosis Patients on Treatment in Northwest Ethiopia: a Longitudinal Study. J Nutr Disorders. 2014;4(2). doi:10.4172/ 2161-0509.1000143

18. Nambi E. Prevalence and Factors Associated with Malnutrition Among Adult Tuberculosis Patients Attending the National Referral Tuberculosis Program Clinic at Mulago Hospita. Makerere University; 2015.

19. Sitienei K, Kipruto H, Borus PV, Nyambati JC, Kihara Anne JBR. Predictors of Low Body Mass Index Among Patients with Smear Positive Pulmonary Tuberculosis patients on three high Tb burden provinces in Kenya. Int J Tropical Dis Health. 2014;4(4):427-436. doi:10.9734/IJTDH/2014/6387
20. Dargie B, Tesfaye G, Worku A. Prevalence and associated factors of undernutrition among adult tuberculosis patients in some selected public health facilities of Addis Ababa, Ethiopia: a cross-sectional study. BMC Nutrition. 2016;2(1):7. doi:10.1186/s40795-016-0046-x

21. Geberemeskel T, Woldeyohannes D, Demisie M, Demisie M. Undernutrition and Associated Factors among Adult Tuberculosis Patients in Hossana Town Public Health Facilities, Southern Ethiopia. J Trop Dis. 2018;6:253. doi:10.4172/2329-891X.1000253

22. Di Gennaro F, Vittozzi P, Gualano G, et al. Active Pulmonary Tuberculosis in Elderly Patients: a 2016-2019 Retrospective Analysis from an Italian Referral Hospital. Antibiotics. 2020;9 (8):489. doi:10.3390/antibiotics9080489

23. Samuel B, Volkmann T, Cornelius S, Mukhopadhay S. Relationship between nutritional support and tuberculosis treatment outcomes in West Bengal, India. J Tuberculosis Res. 2016;4(4):213. doi:10.4236/ jtr.2016.44023

24. Tesfaye A Magnitude of Undernutrition and Associated Factors among Adult Tuberculosis patients attending Government Health care Facilities of Shashemane. Ethiopian Public Health Association 28th annual conference; 2016. Available form: https://etpha.org/con ference/index.php/28thConference/28thConference/paper/view/400. Accessed April 8, 2021.

25. Begashaw B, Mekiso A, Legesse T. Prevalence of pulmonary tuberculosis and associated factors among prisoners in Wolaita Zone, Southern Ethiopia: cross-sectional Study. Am J Public Health Res. 2016;4(4):142-148.
Nutrition and Dietary Supplements

\section{Publish your work in this journal}

Nutrition and Dietary Supplements is an international, peerreviewed, open access journal focusing on research into nutritiona requirements in health and disease, impact on metabolism and the identification and optimal use of dietary strategies and supplements necessary for normal growth and development. The journal welcomes submitted papers covering original research, basic science,

\section{Dovepress}

clinical \& epidemiological studies, reviews and evaluations, guidelines, expert opinion and commentary, case reports and extended reports. The manuscript management system is completely online and includes a very quick and fair peer-review system, which is all easy to use. Visit http://www.dovepress.com/testimonials.php to read real quotes from published authors. 